Journal of Engineering and Applied Sciences 14 (Special Issue 7): 9950-9954, 2019

ISSN: 1816-949X

(C) Medwell Journals, 2019

\title{
Influence of Alloying Element on Corrosion Behavior of (Al-Li) Alloys used in Aerospace Industries
}

\author{
K. Abdalwahid, Rajih Enass and L. Ali \\ College of Materials Engineering, University of Babylon, Hillah, Iraq
}

\begin{abstract}
Al-Li) alloys contain certain alloying elements exhibit high elastic modulus, high strength and low density. These properties are main requirements in aerospace industries. These alloys are subjected to corrosion and corrosion/erosion during the application. The corrosion behavior was investigation on a function of alloying elements and corrosion medium. Tafel technique was adopted to record the corrosion current. Corrosion/erosion were determined by suitable equipment. Results obtained showed that tests conducted in tap water showed that corrosion current of Al-Li-Cu was 7\% of the corresponding value of the reference alloy (Al-Li). $\mathrm{In}_{2} \mathrm{SO}_{4}$, however, it was $14 \%$ with respect to the base alloy. For (Al-Li-Cu-Mg) alloy the corrosion current in tap water was only $2.5 \%$ with respect to the base alloy (Al-Li). $\mathrm{In}_{2} \mathrm{SO}_{4}$ the corrosion current was $67 \%$ with respect to the base alloy. In corrosion/erosion test, the weight (loss/area) the base metal (Al-Li) was $4.4 * 10^{-6} \mathrm{~g} / \mathrm{mm}^{2}$. For (Al-Li-Cu) alloy it was only $0.95 * 10^{-6} \mathrm{~g} / \mathrm{mm}^{2}$ while (Al-Li-Cu-Mg) alloy gives $1.95^{*} 10^{-6} \mathrm{~g} / \mathrm{mm}^{2}$.
\end{abstract}

Key words: (Al-Li) alloys, corrosion/erosion, tafel tests, function, determined, corrosion

\section{INTRODUCTION}

$\mathrm{Al}$ alloys contain lithium offer attractive potentials for aerospace industry. $\mathrm{Li}$ is the only element which when added to aluminum increases elastic modulus and strength and decreases density. The chief obstacle to wide-spread application of $\mathrm{Al}-\mathrm{Li}$ alloys appears to be their low fracture toughness. Up to the present time, a high strength, high toughness alloy has not been developed. It is possible, though that significantly improved alloys will be found.

In order to advance the payload and fuel efficiency of aircrafts, the Al-Li alloys have been significantly used in aerospace industries because of their attractive arrangement of properties such as higher specific strength, lower density and elastic modulus than the conventional commercial 2 and $7 \mathrm{xxx}$ type aluminum alloys (Decreus et al., 2013; Rajendran et al., 2009). With the improvement of aerospace industry, the demands of industrial large integrally stiffened lightweight panels are much more urgent (Williams and Starke, 2003; Kim et al., 2007). Age forming, an advanced forming technique that combines mechanical forming and age hardening has been developed rapidly to solve the problem that conventional plastic forming could not solve (Zhang et al., 2013; Inforzato et al., 2012). Age forming possesses the advantages of the material safety, the excellent mechanical properties as well as the repeatable process which has been successfully used to produce airplane upper wing skins in these years (Chen et al., 2014).
Table 1: The alloys chemical composition (wt.\%)

\begin{tabular}{lllll}
\hline Codes & Al & $\mathrm{Li}$ & $\mathrm{Cu}$ & $\mathrm{Mg}$ \\
\hline A & Bal. & 2 & - & - \\
B & Bal. & 2 & 3.57 & - \\
C & Bal. & 2 & 3.40 & 0.35 \\
\hline
\end{tabular}

\section{MATERIALS AND METHODS}

Experimental procedures: The (Al-Li) alloys composition used was analyzed by SPECTOMAXX (Germany) and the composition is shown in Table 1. The samples were prepared by casting at a temperature of $800^{\circ} \mathrm{C}$ by the gas furnace and then samples were placed in a heating furnace which working together at $525^{\circ} \mathrm{C}$ for $6 \mathrm{~h}$. After that, they were hot rolled at $260^{\circ} \mathrm{C}$ to reduce the thickness of the samples from $8-5 \mathrm{~mm}$, then specimens were heat treated at $560^{\circ} \mathrm{C}$ for an hour and then quenched in cold water at $8^{\circ} \mathrm{C}$. Finally, artificial aging at $175^{\circ} \mathrm{C}$ for 16 has shown Fig. 1.

Corrosion tests: These tests were carried out by Tafel extrapolation technique. Tap water and $\mathrm{H}_{2} \mathrm{SO}_{4}$ were used to study the corrosion behavior of the examine samples. Corrosion current and electrode potential as shown in Fig. 2, corrosion rate measurement is obtained by using the following Eq. 1:

$$
\text { Corrosion rate }=\frac{0.13 \operatorname{Icorr}(\mathrm{Ew})}{\rho}
$$

Where:

E.W : Equivalent Weight (g/eq.) $=$ Density $\left(\mathrm{gcm}^{-3}\right)$

0.13 : Metric and time conversion factor

icorr.: Current density $\left(\mu \mathrm{Acm}^{-2}\right)$

mpy : Corrosion rate (mils per year) (Fig. 2) 


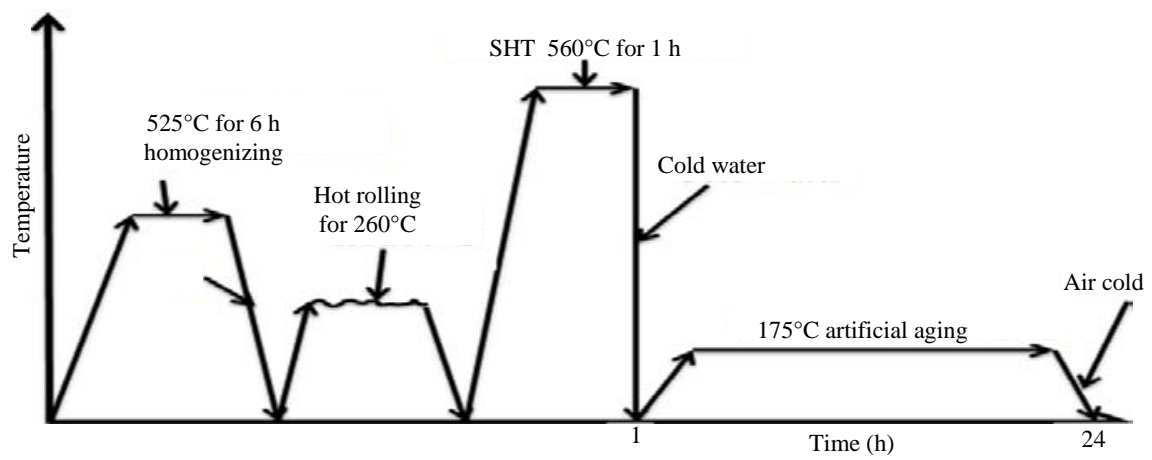

Fig. 1: Work plan for research

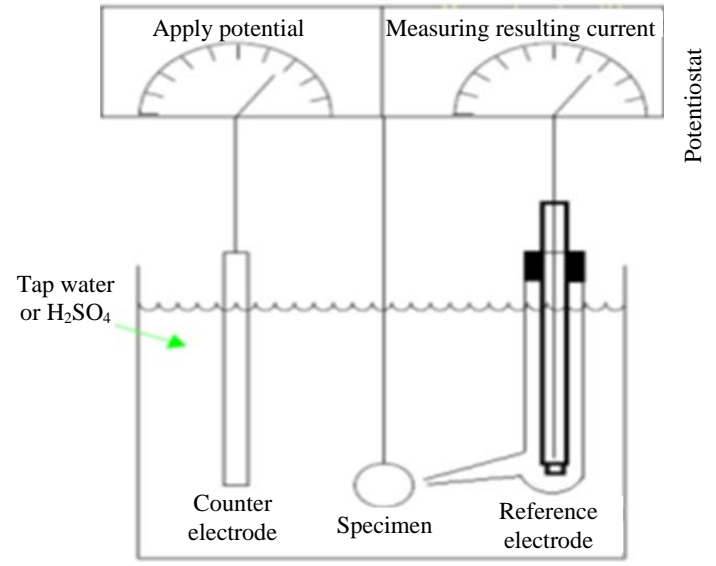

Fig. 2: Schematic diagram of potentiodynamic polarization cell

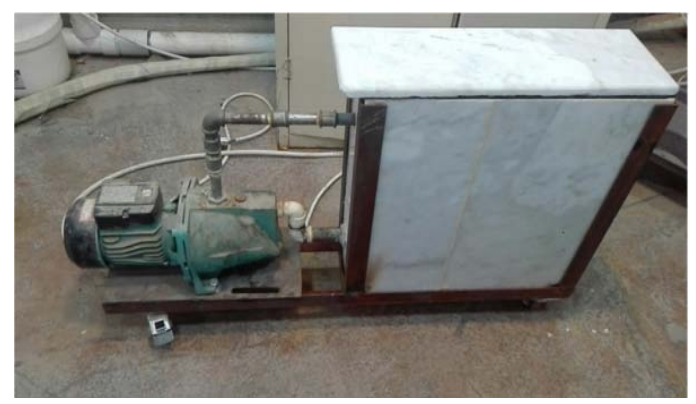

Fig. 3: Erosion-corrosion apparatus depend on (G73) ASTM. This device designed during the study

Erosion/corrosion tests: The erosion is a mechanical process such as remove part of the material from the surfaces because of the collision or gases and liquid effects. The erosion/corrosion apparatus was designed during our study depends on (G 73) ASTM as shown in Fig. 3. The erosion-corrosion apparatus consists of generator motor, granite tank, tubes to fall the water by nozzle on the specimen. All alloys examined temperature (25-30) wherever taps water will causing erosion-corrosion and fall from the nozzle at $90^{\circ} \mathrm{C}$ at $1.12 \mathrm{~m} / \mathrm{sec}$. The nozzle has a diameter one millimeter and has tenmillimeters from the alloy.

Density measurement: To measure the density in a practical way for the purpose of determining the density of the alloys, sensitive balance of \pm 0.0001 was used to measure the alloy and the electronic weight meter was used shown Eq. 2. The reading is based on the linear potentiometer where \pm 0.02 is used to measure sample dimensions for the size calculation density Eq. 2:

$$
\rho=\frac{\mathrm{W}_{\text {air }}}{\mathrm{W}_{\text {air }}-\mathrm{W}_{\text {water }}} * \rho_{\text {water }}
$$

Where:

( $\rho) \quad$ : The alloy density $\left(\mathrm{gcm}^{-3}\right)$

$\left(\mathrm{W}_{\text {air }}\right)$ : Alloy net Weight in the air (g)

$\left(\mathrm{W}_{\text {water }}\right)$ : Alloy Weight in the water (g)

$\left(\rho_{\text {water }}\right)$ : Density of water $\left(\mathrm{gcm}^{-3}\right)$

\section{RESULTS AND DISCUSSION}

Corrosion tests: Tafel extrapollerization technique was used to measure the corrosion current Fig. 4-9. Corrosion current of the tested alloys in tap water and $\mathrm{H}_{2} \mathrm{SO}_{4}$ are shown in Table 2.

It is clear from above that the corrosion current of $\mathrm{Al}-\mathrm{Li}-\mathrm{Cu}$ in tap water was only $7 \%$ with respect to the reference alloy (Al-Li). For Al-Li-Cu-Mg, however, it was $2.5 \%$ with respect to the Al-Li alloy. For $\mathrm{Al}-\mathrm{Li}-\mathrm{Cu}$ in $\mathrm{H}_{2} \mathrm{SO}_{4}$, it was $14 \%$ with respect to the reference alloy. And $67 \%$ for $\mathrm{Al}-\mathrm{Li}-\mathrm{Cu}-\mathrm{Mg}$ with respect to the base alloy.

Microstructure Fig. 10 examination showed a variation in grain size. Fine grains enhance the diffusion of protective scale building. This why variation in corrosion behavior was observed.

Corrosion/erosion: Great improvement was observed in the corrosion/erosion resistance. For instance, the weight 


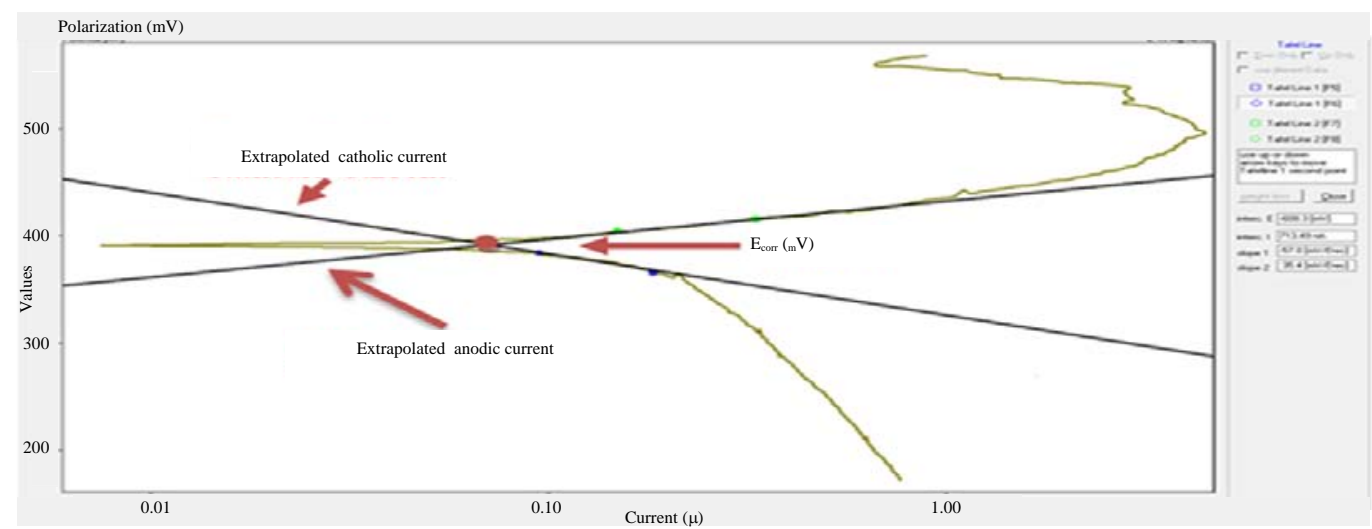

Fig. 4: Curve polarization of A alloy in a tap water

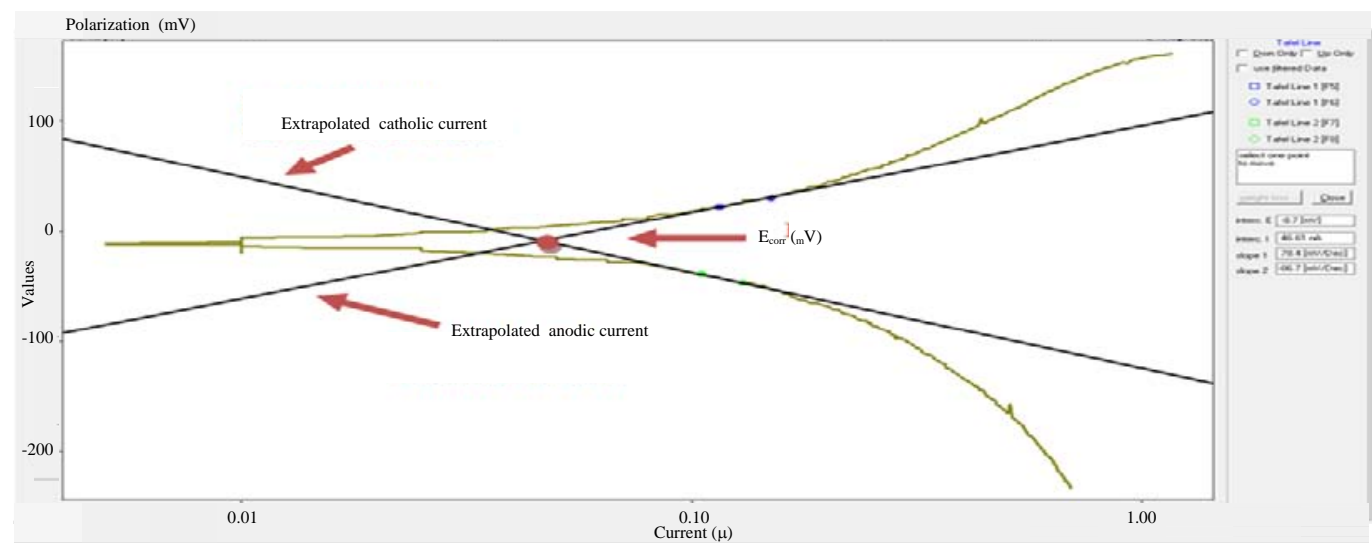

Fig. 5: Curve polarization of B alloy in a tap water

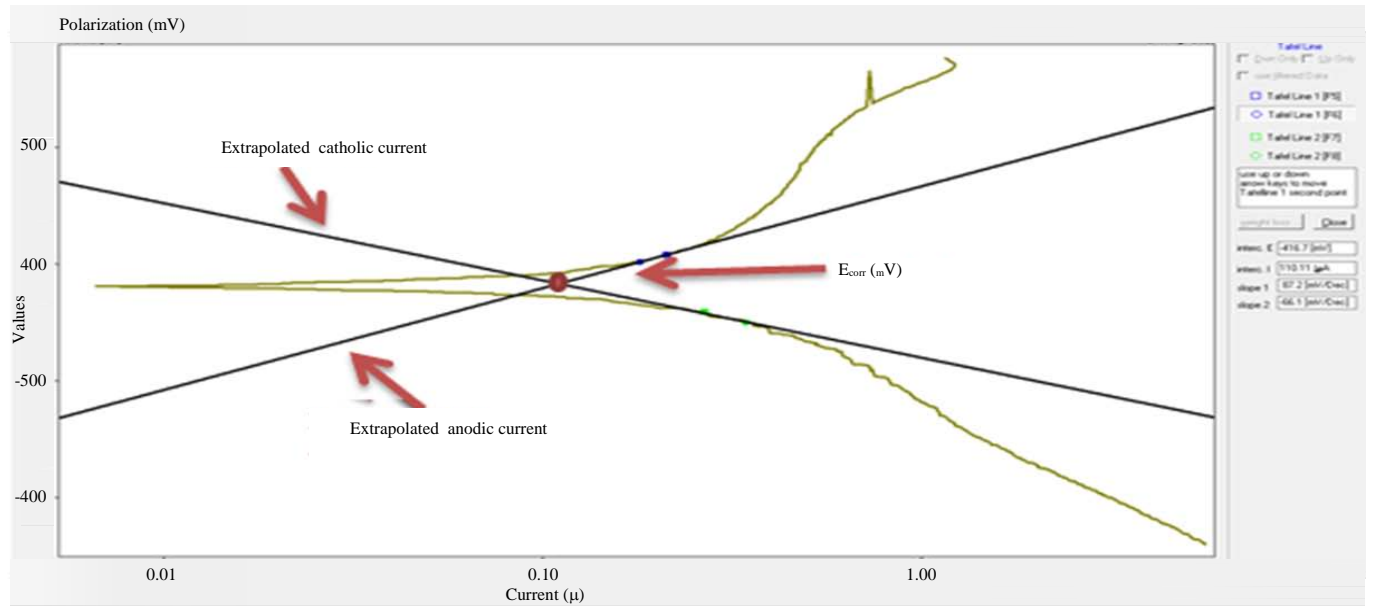

Fig. 6: Curve polarization of $\mathrm{C}$ alloy in a tap water

loss after $5 \mathrm{~h}$ was only $0.95 * 10^{-6} \mathrm{~g} / \mathrm{mm}^{2}$ compared to the base metal (Al-Li). For Al-Li-Cu-Mg it was only $1.95 * 10^{-6} \mathrm{~g} / \mathrm{mm}^{2}$ ) with respect to the base metal as shown in Fig. 11-13. This improvement may be attributed to the grain structure (diffusivity) of protective oxide building elements and to the hardness of the alloys. 


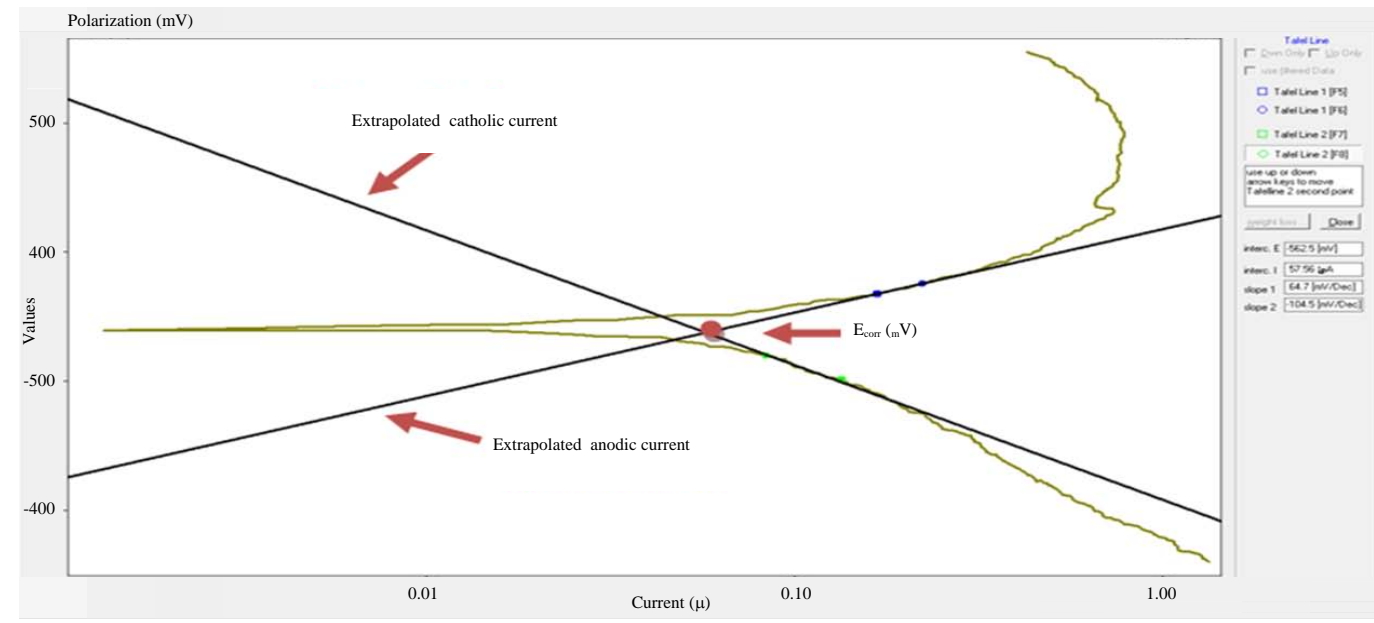

Fig. 7: Curve polarization of A alloy in acid solution $\mathrm{H}_{2} \mathrm{SO}_{4}$

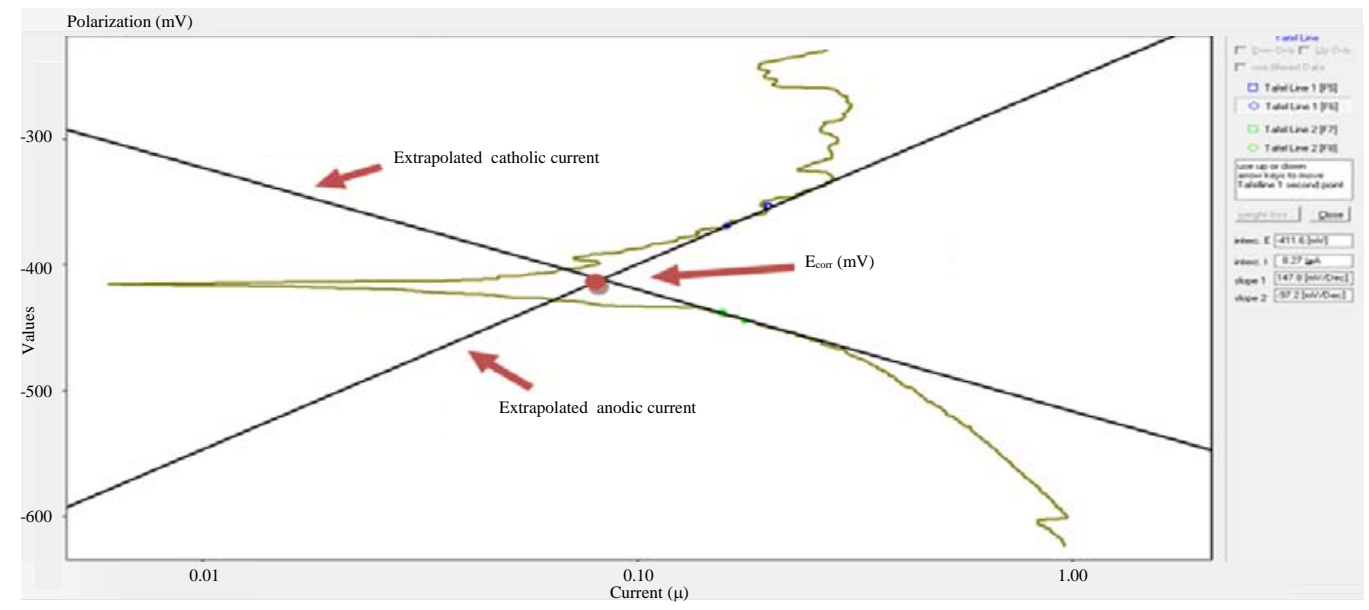

Fig. 8: Curve polarization of B alloy in acid solution $\mathrm{H}_{2} \mathrm{SO}_{4}$

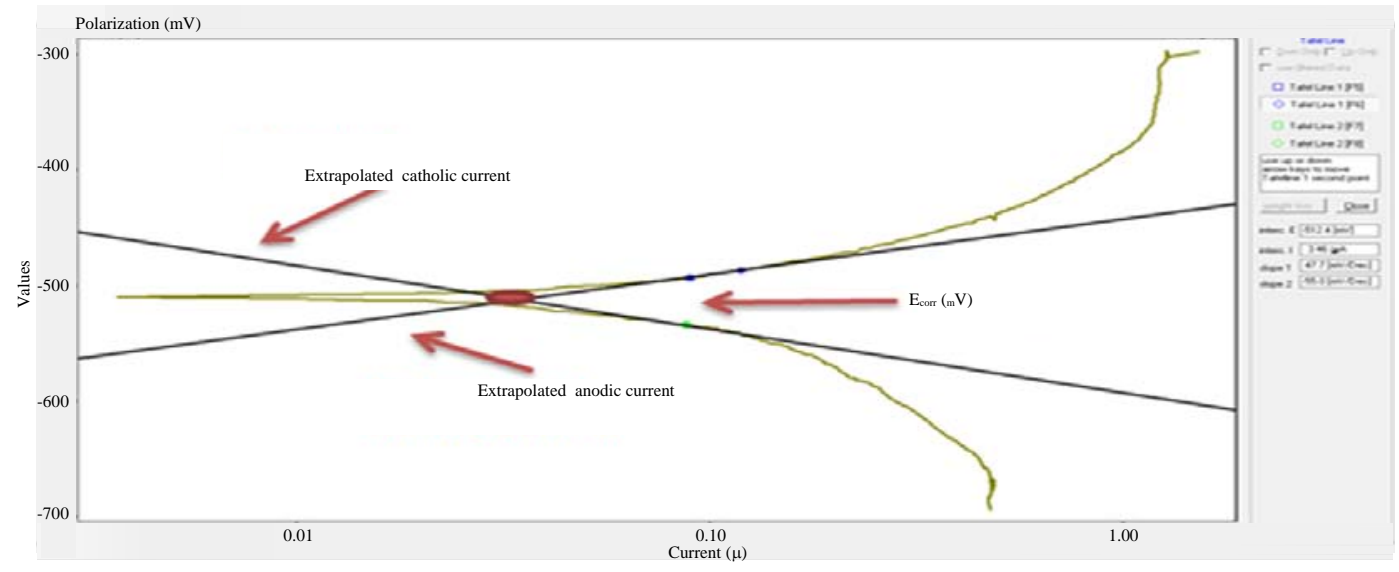

Fig. 9: Curve polarization of $\mathrm{C}$ alloy in acid solution $\mathrm{H}_{2} \mathrm{SO}_{4}$ 
Table 2: Results of corrosion in the case of tap water and $\mathrm{H}_{2} \mathrm{SO}_{4}$

\begin{tabular}{|c|c|c|c|c|c|c|}
\hline \multirow[b]{2}{*}{ Alloys } & \multicolumn{3}{|l|}{ Tap water } & \multicolumn{3}{|l|}{$\mathrm{H}_{2} \mathrm{SO}_{4}$} \\
\hline & $E_{\text {corr }}(\mathrm{mV})$ & $I_{\text {corr }}(n A)$ & CR (mpy) & $\mathrm{E}_{\text {corr }}(\mathrm{mV})$ & $I_{\text {corr }}$ & CR (mpy) \\
\hline Al-Li & -608.3 & 713.49 & 0.03 & -562.5 & 57.56 & 2.650 \\
\hline Al-Li-Cu & -8.7 & 46.60 & $2.12 * 10^{-4}$ & -411.6 & 8.27 & 0.037 \\
\hline Al-Li-Cu-Mg & -439.7 & 18.54 & 0.422 & -536.8 & 38.76 & 0.176 \\
\hline
\end{tabular}

Table 3: Density of alloys

\begin{tabular}{lccc}
\hline Alloys & A & B & C \\
\hline Density $\left(\mathrm{gcm}^{-3}\right)$ & 2.52 & 2.60 & 2.51 \\
\hline
\end{tabular}
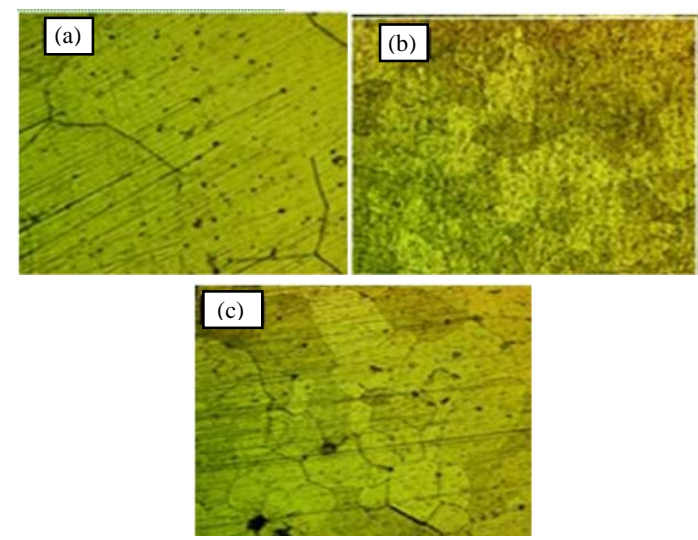

Fig. 10 Microstructure of alloys at $100 \mathrm{X}$ magnification (a) After aging $16 \mathrm{~h}$ (b) After aging $20 \mathrm{~h}$ and (c) After aging $8 \mathrm{~h}$

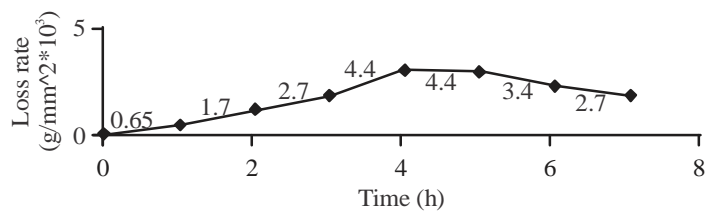

Fig. 11: Effect of period of exposure to tap water in lost weight of alloy A

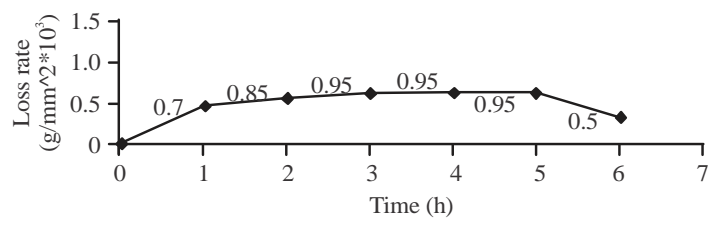

Fig. 12: Effect of period of exposure to tap water in lost weight of alloy B

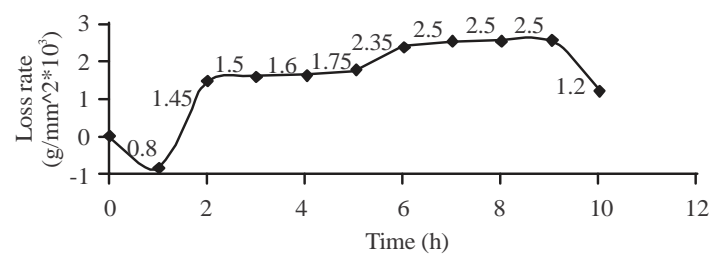

Fig. 13: Effect of period of exposure to tap water in lost weight of alloy $\mathrm{C}$
Density: The density of the alloys in the archimedes base method is shown in Table 3. The density tests carried out for all the alloys used in this study were all less than the density of (Al-Cu) alloy originally used in the hull of aircraft. This provides more load and speed.

\section{CONCLUSION}

The following conclusion may be drawn from this research. Alloys from the three generation of Al-Li alloys series were chosen and tested. Significant improvement in corrosion resistance was observed in several alloys in tap water. For instance, the weight loss of alloy B was only $7 \%$ of the corresponded value of the reference. In acid solution, however, the weight loss of alloy B was only $14 \%$ compared with the reference. Significant improvement in corrosion resistance was observed in several alloys in tap water. For instance the weight loss of alloy $\mathrm{C}$ was only $2.5 \%$ of the corresponded value of the reference. In acid solution, however, the weight loss of alloy $\mathrm{C}$ was only $67 \%$ compared with the reference.

\section{REFERENCES}

Chen, J.F., J.T. Jiang, L. Zhen and W.Z. Shao, 2014. Stress relaxation behavior of an Al-Zn-Mg-Cu alloy in simulated age-forming process. J. Mater. Process. Technol., 214: 775-783.

Decreus, B., A. Deschamps, F. De Geuser, P. Donnadieu and C. Sigli et al., 2013. The influence of $\mathrm{Cu} / \mathrm{Li}$ ratio on precipitation in Al-Cu-Li-x alloys. Acta Mater., 61: 2207-2218.

Inforzato, D.J., P.R. Costa Junior, F.F. Fernandez and D.N. Travessa, 2012. Creep-age forming of AA7475 aluminum panels for aircraft lower wing skin application. Mater. Res., 15: 596-602.

Kim, J.M., K.D. Seong, J.H. Jun, K. Shin and K.T. Kim et al., 2007. Microstructural characteristics and mechanical properties of Al-2.5 wt.\% Li-1.2 wt.\% Cu-xMg alloys. J. Alloys Compd., 434: 324-326.

Rajendran, V., S.M. Kumaran, T. Jayakumar, P. Palanichamy and P. Shankar et al., 2009. Microstructure and ultrasonic behaviour on thermal heat-treated Al-Li 8090 alloy. J. Alloys Compd., 478: 147-153.

Williams, J.C. and E.A. Starke, 2003. Progress in structural materials for aerospace systems. Acta Mater., 51: 5775-5799.

Zhang, J., Y.L. Deng, S.Y. Li, Z.Y. Chen and X.M. Zhang, 2013. Creep age forming of 2124 aluminum alloy with single/double curvature. Trans. Nonferrous Met. Soc. China, 23: 1922-1929. 